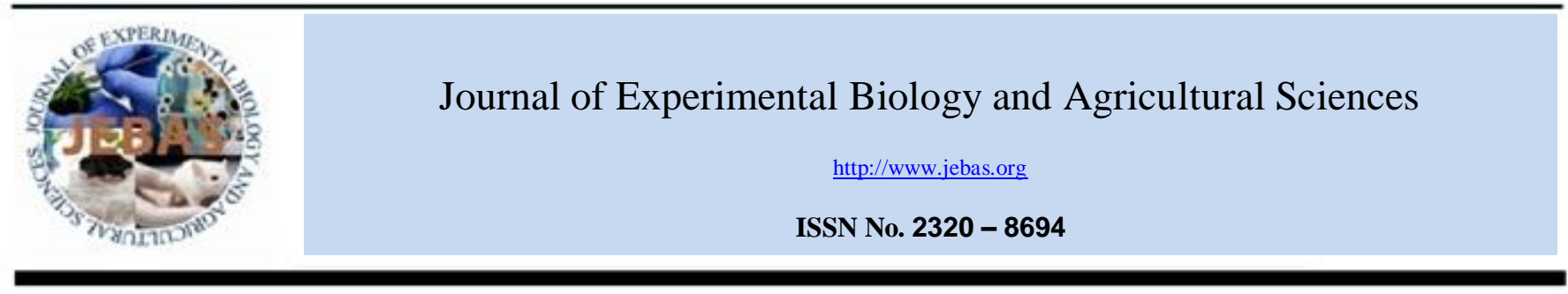

\title{
LIVELIHOOD ASSESSMENT OF THE FISHERMEN COMMUNITY IN THE SOUTH WEST REGION OF BANGLADESH
}

\author{
Mridula Rani Das ${ }^{1}$, Sunuram Ray $^{2}$, Uttam Kumar ${ }^{3, *}$ Salma Begum ${ }^{4}$ and Satya Ranjan Tarafdar ${ }^{5}$ \\ ${ }^{1,4}$ Environmental Science Discipline, Khulna University, Bangladesh \\ ${ }^{2}$ Centre for Integrated Studies on the Sundarbans (CISS), Khulna University, Bangladesh \\ ${ }^{3}$ World Vision International, Bangladesh \\ ${ }^{5}$ Development Activist, Bangladesh
}

Received - June 03, 2015; Revision - June 18, 2015; Accepted - August 05, 2015

Available Online - August 20, 2015

DOI: http://dx.doi.org/10.18006/2015.3(4).353.361

\begin{abstract}
KEYWORDS
Fishermen

Livelihood

Batiaghata Upazila

Khulna

Bangladesh

ABSTRACT

This study was undertaken to update the livelihood status of fishermen community in Batiaghata upazila of Khulna district from February to December, 2013. The data were collected through the questionnaire, survey, group discussion and public interview. The results of the study revealed some interesting facts and showed that most of involved fishermen are in 16-30 years age group (45\%) whereas majority of them were Hindu (62\%). About $75 \%$ of fishing community was illiterate and $24 \%$ was literate. Furthermore, it was reported that about $78 \%$ of the fishermen received treatment from Village doctors ( have little medical knowledge, mostly quack) and only $20 \%$ of the respondents concern the doctors from upazila health complex and left over $2 \%$ got health service from MBBS doctors outside the upazila. It was found that $61 \%$ house were Kacha (Made of mud and straw) while 37\% house were Semi-pucca (Tin shed building) and only $2 \%$ house were pucca. (Bricks Built house) About 23\% of fishermen had ability to access electricity and others $77 \%$ had no access to electricity. No Vulnerable Group Feeding cards were provided by government for them in those areas. Lack of proper knowledge, illiteracy not as much of governmental support was the major constraints.
\end{abstract}

* Corresponding author

E-mail: uttammitra@ hotmail.com (Uttam Kumar)

Peer review under responsibility of Journal of Experimental Biology and Agricultural Sciences

Production and Hosting by Horizon Publisher (www.myvision.webs.com/horizon.html)

All rights reserved.
All the article published by Journal of Experimental Biology and Agricultural Sciences is licensed under a Creative Commons Attribution-NonCommercial 4.0 International License Based on a work at www.jebas.org.

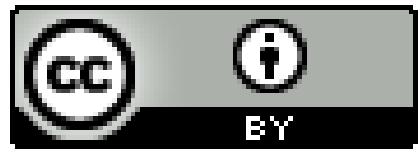




\section{Introduction}

Fish and fisheries products play a Significant socioeconomic role of Bangladesh in terms of nutrition, income, employment and foreign exchange earnings and depend on fish as the principal source of animal protein. More than 80 percent of the animal protein in the Bangladeshi diet comes from fish products. Fisheries sector contribute about $90 \%$ of the nation's animal protein intake, nearly 6 to $8 \%$ GDP to national income and $5.77 \%$ to the foreign earning of nation (DoF, 2012). Annual fish production was 2,701,370MT in 2008-09 where annual fish intake by an individual is $17.52 \mathrm{~kg}$ and the annual fish demand is 29.74 MT (DoF, 2010). It is estimated that about 12 million people are directly or indirectly engaged in fishing and other ancillary fishery activities and a large portion of rural family members are engaged in part time fishing from the beels (Hughes et al., 1994). About 12 million people of the country directly or indirectly involved in fisheries and other ancillary activities (DoF, 2013). Livelihood is sustainable when it can cope with stresses \& shocks and maintain or enhance its capabilities to recover from it, while not undermining the natural resource base (Chambers \& Conway, 1992). For sustainable rural development and poverty elimination, different approaches had been adopted and the sustainable livelihood approach has been gradually expanded with its own core and principles for poverty focused development activities (DFID, 1999). The approach basically based on the fundamental principle analysis of capital assets in the context of the external environment. Scoones (1998) addressed that a sustainable livelihood is a way of thinking about the objectives, scope and priorities for development, in order to enhance progress in poverty elimination.

Batiaghata upazila is adjacent to the Khulna town is one of the most important ecosystem with much aquaculture impending. This area is known as a fishery polli which play a very important role in alleviation of rural poverty and supplying food to the poor fishing community. Large scope of fish

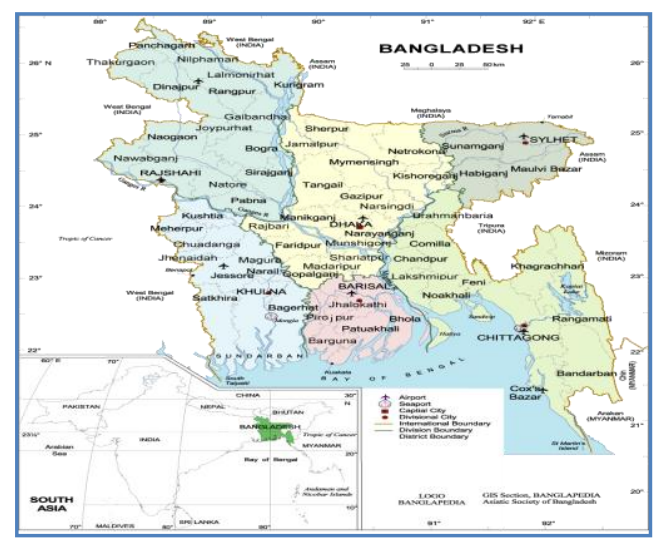

culture system would be possible if fish farmers adopt improve technology and most of the fishermen in this area uses traditional fishing method. However, socioeconomic status of this fishing community is not reasonable; production of fish is also declining day by day. Considering the above fact, the present study was conceded to assess the livelihood status and constraint faced by the fishermen in the study. For this reason, Batiaghata upazila was selected for the study to identify socioeconomic condition of the fish farmers.

\section{Material and Methods}

\subsection{Study area and duration}

This study was carried out in Batiaghata upazila of Khulna district, Bangladesh. The study areas located between $22^{\circ} 34^{\prime}$ to $22^{\circ} 46^{\prime}$ Latitude and $89^{\circ} 24^{\prime}$ to $89^{\circ} 37^{\prime}$ Longitude. The study period was from February to December, 2013 (figure 1).

\subsection{Sampling frameworks}

The study was composed of a livelihood systems assessment, coastal regions of south-western Bangladesh. The primary data were collected through the questionnaire, survey, group discussion and interview. Weekly field survey was carried out to collect the necessary information through random selection method. A total of 100 fishermen households were surveyed in ten villages, viz-Jharbanga, Machalia, Tengramari, Katiadangla, Amtala, Titukhali, Andharia, Khejurtala, Persolua and Brittisolua under Gangarampur union, Batiaghata upazila. However, all the data were cross-checked for ensuring the accuracy of data collected from the respondents. The Focus Group Discussion were conducted to identify the problems and to collect fishermen's recommendations regarding the problems identified so that effective solution to the problems would develop. Necessary information on the socio- economic condition of fishermen was collected from regional fisheries, settlement, LGED and agricultural offices.

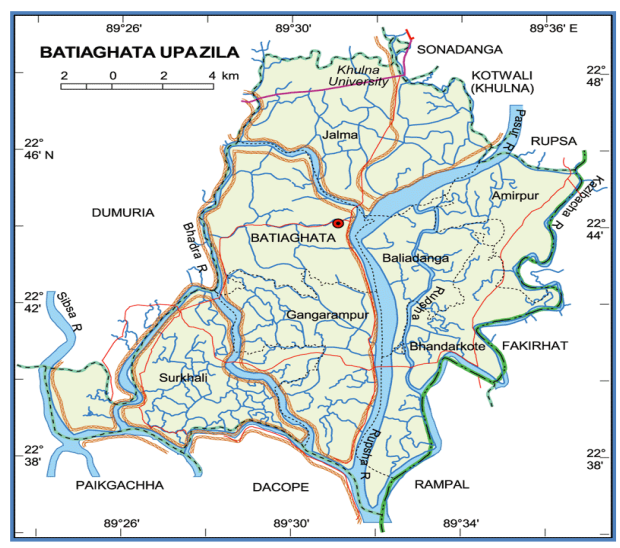

Figure 1 Location of study area in Batiaghata upazila under Khulna district, Bangladesh. 


\section{Results and Discussion}

Total 100 fishermen were interviewed and it was reported that the socio-economic condition of fishermen using the survey indicators like, sex ratio, religion status, age distribution marital status, educational status, house type, latrine, daily intake of meal, diseases and treatment, land owner, occupation, expenditure, monthly income, earn from per travel to the sea, trends of fishing faced various levels problems. A detailed analysis is made on these parameters and presented in this section.

\subsection{Sex Distribution}

Results of the sex ratio and religion related study suggested that total $82 \%$ male and $18 \%$ female respondents were actively involved in the fishing (figure 2). DoF (1993) studied on different coastal districts of Bangladesh and showed involvement of sex ratio, male: female was 90:10 in fishing.

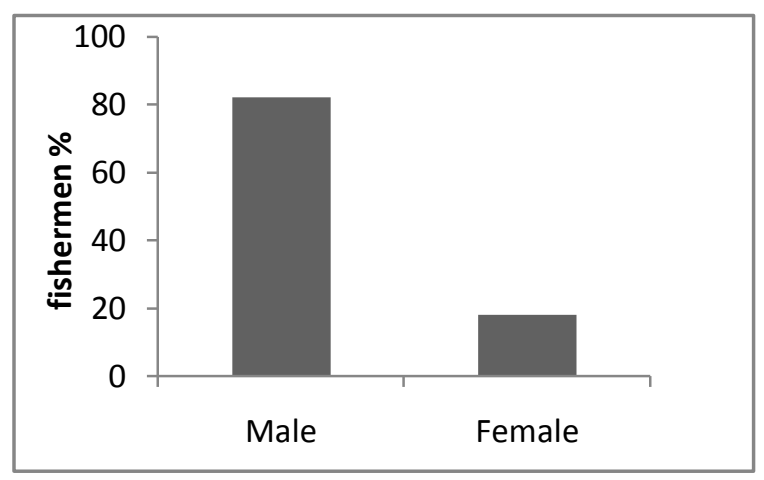

Figure 2 Sex distribution related to the fishing

\subsection{Age distribution}

Knowledge of age distribution of the fishermen is important in estimating potentiality of the human resources. In the present study, age classified into five groups as $0-15,16-30,31-45$, 4660 , and 61-75 years that presented in the figure 3 . The investigation showed majority of the fishing professional belongs to the 16-30 age group (45\%) while the 61-75 aged class has been lowest involvement (4\%).

Results of the study are controversial than the Minar (2012) and revealed that 31-40 old people are highest (56\%) and 4160 aged people are the lowest (14\%) involved in fishing. In another study Kostori (2012) revealed that majority (36\%) fishermen of chalan Beel were belonging to age group of 2030 years and these findings are in accordance with the findings of present study.

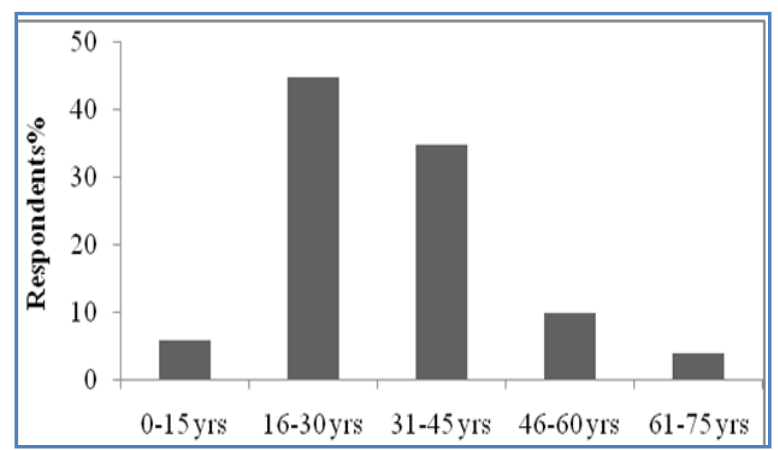

Figure 3 Age distribution of the respondent fishermen

\subsection{Family type and family size}

Trends of joint family are continuously decreasing in the fishermen society of Bangladesh. This may be due to the poor economic condition and different natural calamities of the fishermen. Result of the present study showed that maximum numbers of studied fishermen leaved in single family $(76 \%)$ while very small number of the studied responded prefers extended family (24\%). The table (1) disclosed the number of family people and respondent in the survey.

Table 1 Family size of the studied respondent

\begin{tabular}{|l|l|}
\hline Family Size (Year) & Respondents \% \\
\hline $01-03$ & 9 \\
\hline $04-06$ & 65 \\
\hline $07-09$ & 23 \\
\hline $10-12$ & 2 \\
\hline $13-15$ & 1 \\
\hline
\end{tabular}

\subsection{Educational status}

Many of the fishermen were literate at various levels of education. However, while responding it was found to just class 1 to 10 as literature and such percentage was only $24 \%$. Among the studied responded only one fisherman had passed S.S.C (Secondary School Certificate Exam). Above this level no one had higher education while the maximum studied respondent fishermen $(75 \%)$ were illiterate. Most of the sampled fishermen were compelled to enter into the fishing profession in their early status of their parents and lack of awareness about education. Another important factor is that, there were hardly any educational institutions in this area. For above reasons, most of the fishermen were illiterate of the study area (figure 4). 


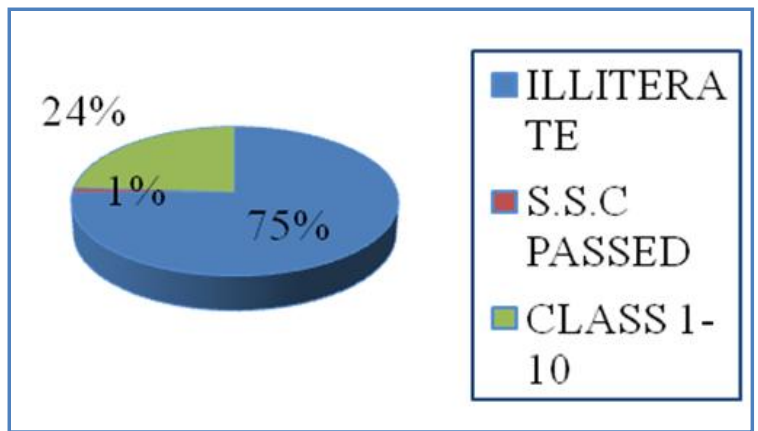

Figure 4 Educational qualification of the respondent fishermen of the study area.

Literacy rate in the fishermen communities was found to be $25 \%$ being defined when a person found to just class- 1 to 10 passed and S.S.C passed. Hossain \& Pingali (1998) and Shahjahan et al. (2001) studied socio-economic condition of the fishermen and reported that majority of the fishermen were illiterate $(71.12 \%$ and $63.33 \%$ respectively) while $24.44 \%$, $31.67 \%$ of the riverine fishermen had only primary level of education and only $4.44 \%, 5 \%$ of them had only secondary level of education respectively. In this aspect results of the present study are in agreement with the findings of Hossain \& Pingali (1998) and Shahjahan et al. (2001).

According to the study of Hannan (1994), majority of the fishermen $(96.97 \%)$ were literate at the various stages of education among the coastal fishing community of the Kalapara Upazilla. Study of Ahamed (1999) in the polder estuaries areas obtained literacy rates $25 \%$ and $23 \%$ respectively. DoF (1993) in chanda beel and Ahamed (1996) in Tangail found literacy rates $45 \%$ and $69 \%$ respectively.

\subsection{Religion status}

Results of the study revealed that the maximum number of studied area fishermen (62\%) belongs to Hindu community while the rest $38 \%$ were belongs to Muslim community.

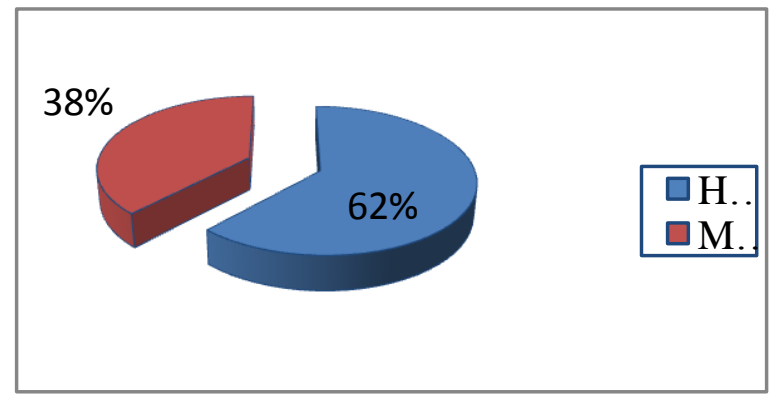

Figure 5 Religion status of the fishermen community.

Results of the present study are in accordance with the findings of Shamima (2000) who had reported that $61.11 \%$ of the fishermen of Gollamari Fishing Community, Khulna were Hindus while $38.89 \%$ were belongs to Muslim community.
These results show similarities with the findings of present study while the findings of Ahamed (1999) are controversial to the present study and he reported that in coastal area showed majority of the fishermen are Muslims (68.33\%) (figure 5).

\subsection{Ownership of house and house types}

Present study showed that a great portion of fishermen were either landless or nearly landless people. Among the studied respondents, about $60 \%$ of fishermen were landless and they had no arable land and about $30 \%$ of the fishermen owned only 1-40 decimal homestead land (figure 6). Ahamed (1996) reported that $94 \%$ fishermen household live in their own house. Furthermore, Mannu (1999) reported that 28\% of fishermen constructed house on the khal land outside of the dam, $36 \%$ were owner land of the house, $8 \%$ in the father laws house and $12 \%$ lived joint with father.

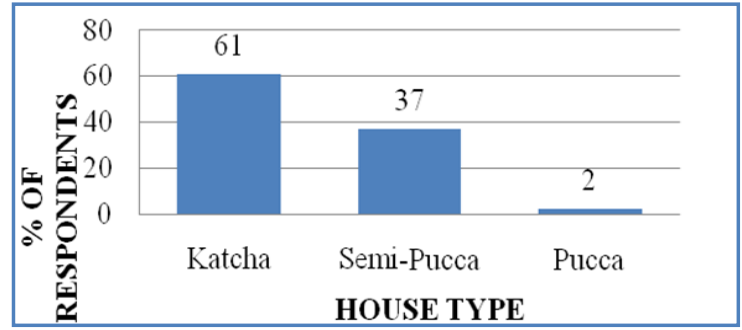

Figure 6 House types of fishermen in the study area.

From the figure, it is clear that $61 \%$ of the studied areas houses were Kacha while the $37 \%$ houses are Semi-pucca and only $2 \%$ houses are pucca. So, economic condition of fishermen of the study area was not well.

\subsection{Use of Electricity}

The study revealed that only $23 \%$ of the fishermen had electricity access while majority (77\%) of them had no electricity access (figure 7). Results of the present study are in accordance with the findings of Shamima (2000) who had reported that $20 \%$ of fishermen had electricity in Gollamari fishing community, Khulna. According to the DoF (2012) only $2 \%$ fishermen household used electricity and in this manner the fishermen of the study areas had better condition with respect to the electricity consumption.

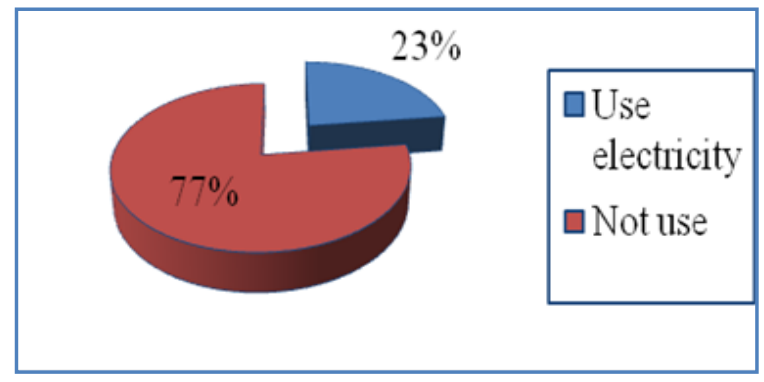

Figure 7 Status of the electricity consumption by the study area fishermen community 
3.8 Working pattern of the fishermen

In the study area, the fishermen caught white fish viz; Vola, Taposhi, Khaira, shrimp (Chaka, Chapne, Horina) etc by using small or medium sized boats. The research estimated that $57 \%$ of fishermen have own-boat and only $18 \%$ of fishermen worked as a day labour in Mohajon's (Usurious) fishing boats (figure 8). They have to go to the river $3-4 \mathrm{Km}$ from their residence for fishing.

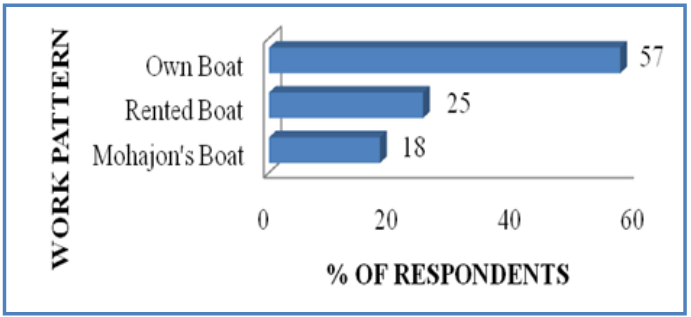

Figure 8 Working patterns of the respondent fishermen

\subsection{Travel based income for going to the river}

The fishermen went to the river 3-4 times in a day for fishing. The study showed that $17 \%$ of the studied fishermen earn monthly income ranged only 0-25 US\$. In present study it was reported that $35 \%$ and $39 \%$ of the study area respondents has monthly income ranged $25-50 \$$ and $50-76.8 \$$ respectively. About 5\%, 3\% and 1\% of fishermen earned 77-102\$, 102-128\$ and $>128 \$$ respectively. So the graph (figure 9 ) revealed that the fishing will not be main tools of fishermen livelihood.

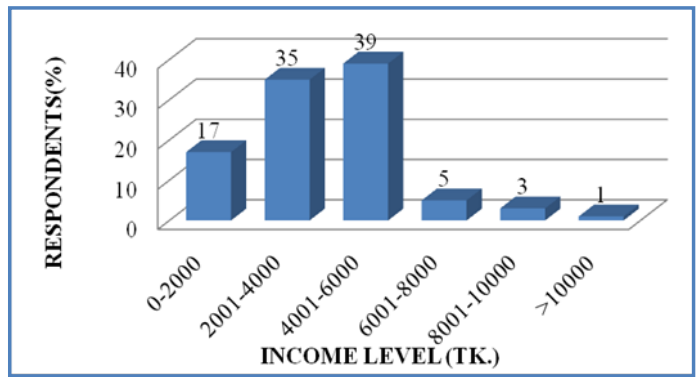

Figure 9 Travel based income level of the respondent fishermen

\subsection{Alternative livelihood options}

Present study estimated that the monthly income rose during June to September but that is not handsome for fishermen. Fishermen opine that tender system has increased their investment costs and their dependency on middlemen. So, the people involved in agriculture, day laboring, business, Vanrickshaw pulling and so on as their secondary and tertiary alternative options. Besides, male and female even child make the net round year. Results of the survey showed that in the year 2003 fishing was the primary occupation for most of the respondent fishermen and with this secondary and other occupational percentages were little bit. But at 2013 their primary occupation was still fishing but their secondary and other occupational percentages status were going to high. The study (figure 10) ensures that fishermen are prone to agriculture, scarcity of fish and bad weather.

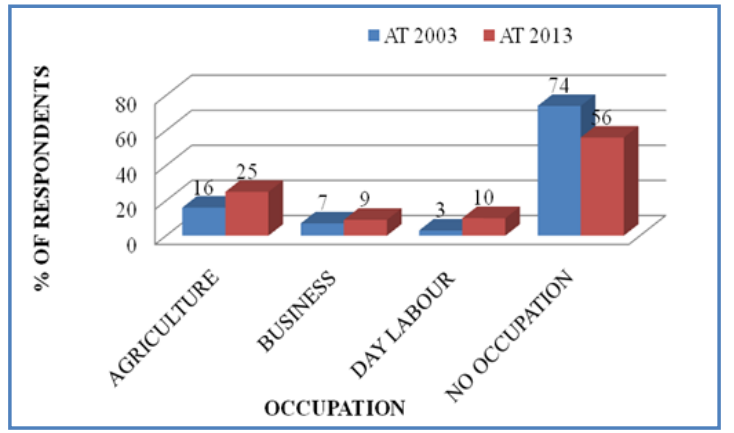

Figure 10 Secondary occupations of the respondent fishermen

\subsection{Changes of income sources}

Maximum fisherman of the study area belongs to poor and underprivileged class. They cannot improve their socioeconomic condition by fishing profession as the income from fisheries sector is continuously reducing. So, they are shifted to other sources.

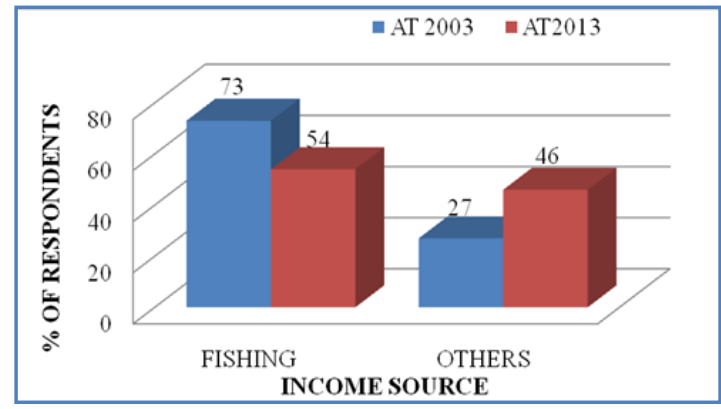

Figure 11 Income percentages from different sources

In the study area, $73 \%$ fishermen were caught fish all the year round dependent family and $27 \%$ were other sources dependent family at 2003. But the graph showed that fishing dependent families were decreasing and other sources dependent families were increasing at the year 2013 (figure 11). Ahamed (1996) found similar result stating $81 \%$ carried out fishing throughout the year. However, Mannu (1999) reported that $72 \%$ were full time fishermen.

\subsection{Problems faced by fishermen}

The fishermen have to catch fishes in good and bad weather condition. They have to go to the river and faces different types of problems during fishing. 


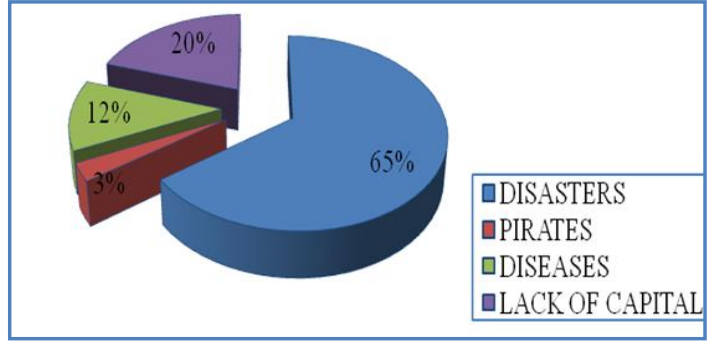

Figure 12 Various problems faced by the fishermen during fishing.

So, they faced different types of problems during fishing. Most of them faced various types of disaster and the percentage of these reached up to $65 \% .12 \%$ fishermen faced problems by diseases, $8 \%$ faced problems by pirates and $20 \%$ faced problems by lack of capital (figure 12). Sometimes, they faced a little bit transportation problems during fishing.

\subsection{Present fish status in the river}

Day after day, fish's populations are decreased in the river and new species of fish are not found in the river. (figure 13) The graph indicates poor condition than previous status of fish.

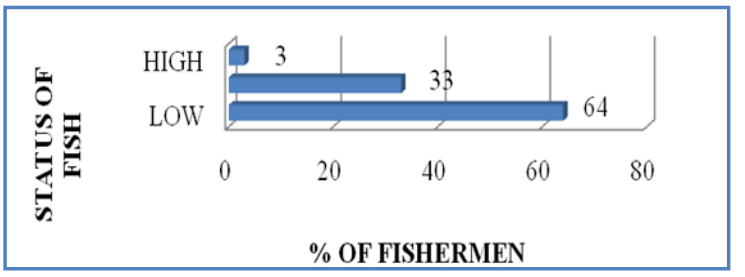

Figure 13 Fishermen perception on status of fish into the river.

From the study it was found that $64 \%$ respondent opined that the present status of fish into the river was low, $33 \%$ believed that medium and only $3 \%$ said that high.

\subsection{Process of fish preservation}

Most of the fishermen caught fishes from nearby river of the study area and try to come back early to the land and sold the fish to the fish market or to the buyers. That's why they did not need any kind of preservation process. Among the studied respondent's fishermen, most of the fishermen did not preserve fish $(65 \%)$ but sometimes they may use ice $(27 \%)$ or other preservative methods $(8 \%)$ for preserving their fish products (figure 14).

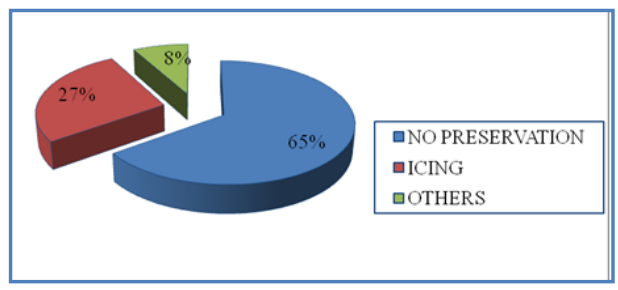

Figure 14 Process of fish preservation

\subsection{Fish selling process}

The pattern of fish selling process was not satisfactory to the fishermen of the study area. The fishermen of the study area were poor. Most of them had no sufficient capital for fishing. They had to take Dadon (High rated loan from usurious) for fishing from moneylenders.

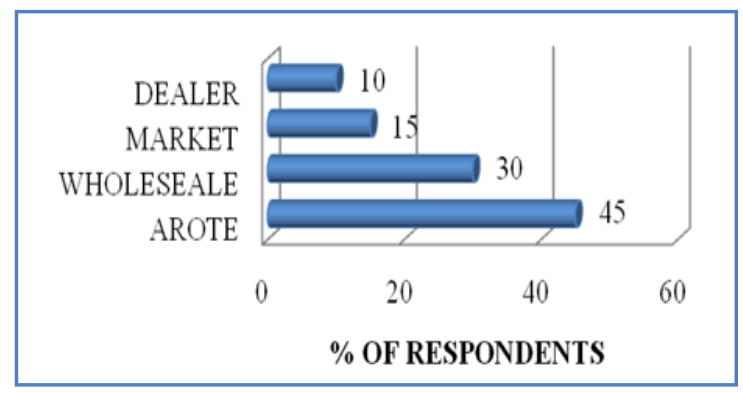

Figure 15 Fish selling process in the study area

Fishermen of the study area were not interested to take Dadon from moneylender. But, they had to take Dadon as they had no enough capital for fishing in the river. Fishermen lend money from Mohajon's for fishing purpose. But, they can't back this money directly. Under such condition, boat was also given by Mohajon's. When the fishermen come back from the river after fishing the whole fishes are taken by the Mohajon's. Mohajon's sold out all the collected fishes and received their loan amount. At first Mohajon's take this money that he gave to the fishermen and then he distributes the rest of the money as condition Mahajan's: Fishermen at 10:6 ratios. From the study (figure 15) it has been reported that the fish were selling to the arot /storehouse (45\%), market (15\%), dealer (10\%) and wholesaler (30\%).

\subsection{Sources of drinking water}

Drinking water have direct effect on the fishermen's health but among the total surveyed respondents only $89 \%$ fishermen used tube-well water for drinking purposes, $3 \%$ used pond water, $7 \%$ used river water and $1 \%$ used other sources of water for drinking and other daily activities (cooking, bathing and washing). In general, women produced in the study area were using drinking water, this does not mean that all had tube-well (figure 16).

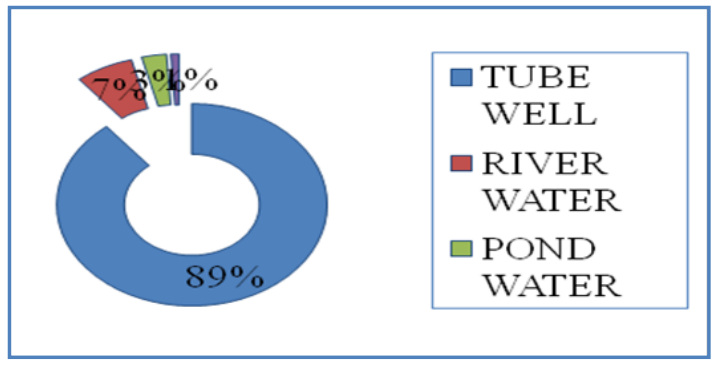

Figure 16 Drinking water sources of fishermen 
Half of the fishermen were found to have their own tube-wells while others are using governmental tube-wells. A number of schools had tube-wells in the survey area and also market place contained one or two tube-wells in the study area. Mahbullah (1986) noted that $41 \%$ fishermen use tube-well water for drinking, cooking, bathing and washing. Rahman \& Hassan (1992) exhibited that $11 \%$ for drinking, cooking and bathing, $18 \%$ for drinking and cooking and $29 \%$ for only drinking in the polder and estuarine fishing community in Bangladesh.

\subsection{Effect of diseases}

All members of the fishermen communities were affected by various diseases viz. Diarrhoea, Fever, Jaundice, Typhoid, Gastritis and so on.

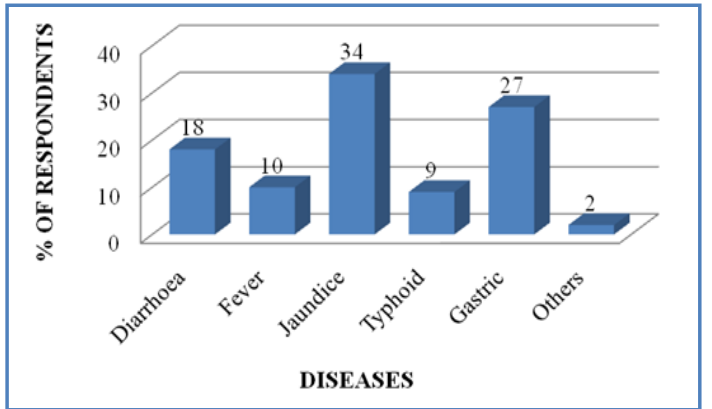

Figure 17 Common diseases among the fishermen of the studied area

From the survey it was found that most of the fishermen suffer from water borne diseases such as Diarrhoea, Jaundice, and Typhoid etc. Majority of them (34\%) suffer from Jaundice while $27 \%$ of them suffer from fever, $18 \%$ of them suffer from Diarrhoea, $10 \%$ of them suffer from Fever and $9 \%$ of them suffer from Typhoid (figure 17). Similar type of observation was made by Samima (2000) who had reported that $52 \%$ fishermen suffered from fever in Gollamari fishing communities, Khulna District. Generally In Bangladesh, there is a significant variation in temperature ranging from 10 to $38^{\circ} \mathrm{C}$; heat stress mortality may be observed among elders, especially during mid-April and mid-August. Due to high temperature and humidity, the elder and malnourished children will face dehydration related problems. A temperature increase of $1 \sim 2^{\circ} \mathrm{C}$ would perhaps not cause a significant, but higher intensity of extreme events may intensify heat stress and associated health hazards.

3.18 Sanitation practice used by fishermen communities

Information was collected on the extent of sanitation practice of the respondent fishermen. Majority of the fishermen (59\%) used katcha latrine for defection in the study area (figure 18).

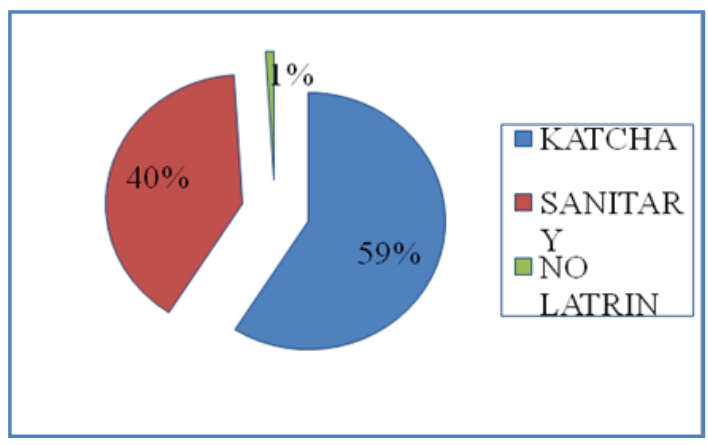

Figure 18 Sanitation practice of the fishermen.

Second majority of the fishermen used sanitary latrine (40\%) for defection and $1 \%$ fishermen had no latrine.

3.19 Fishermen Comments about the Present Condition of the river

Most of the fishermen go for fishing in the river 3-4 km away from their residence. That's why they go as a team of partnership mostly. They go two times in a day for fishing. But, at the time of day of the new moon and night of the full moon they go 3-4 times for fishing because in this time the amount of fishes increased. They have been done this work since 20-30 years. So, they have vast experience about the wave pattern, flow of water, high tide, low tide, the quantity of fishes in the river and the extinction of the fish species in the river. By the following table it is seen that the condition of river is at now vulnerable condition in a great extent. Fishermen said that the price of fish is not good enough to do well their socio-economic condition. Fishing zones are altering and $93 \%$ fishermen were saying that fishing zones are altering and only $7 \%$ are responding negatively (table 2 ). They also said about the decreases of water in river, pond, khal and beel and amount of fish in river.

Table 2 Comments of the fishermen about the river.

\begin{tabular}{|lcccccc} 
Result & $\begin{array}{c}\text { Choice of Fish Price } \\
(\%)\end{array}$ & $\begin{array}{c}\text { Improper } \\
\text { Change }(\%)\end{array}$ & $\begin{array}{c}\text { Fishing Zone Alter } \\
(\%)\end{array}$ & $\begin{array}{c}\text { Are fishes Less Amount } \\
\text { in River? }(\%)\end{array}$ & $\begin{array}{c}\text { Decreases of } \\
\text { water }(\%)\end{array}$ \\
\hline Yes & 3 & 99 & 93 & 100 & 100 \\
\hline No & 97 & 1 & 7 & 0 & 0 \\
\hline
\end{tabular}




\section{Conclusion}

The socio-economic condition of the fishermen in the adjacent area was not satisfactory. The fishermen were deprived of many facilities. The education level of the fishermen was so poor. Lack of awareness as well as the poor income, the fishermen have to take loan from Mohajan at high interest. So why, some educational institutes should be built up in the adjacent area. The Govt. should take some important step by providing some sorts of management policy as well as providing of some extra providence during the ban season of the fishing. That may be done within the providing of the VGF card. Some forms of NGO's activity must be ensured in the adjacent area for the improvement of the life leading status of the fishermen. The NGO's must be helpful about the providence of the loan which may be used for the up gradation of the income procedure. As well as health facilities should be ensured by the government assistance.

\section{Acknowledgement}

Authors are grateful to Environmental Science Discipline, Khulna University, Bangladesh for the technical support to conduct the study.

\section{Conflict of interest}

Authors would hereby like to declare that there is no conflict of interests that could possibly arise.

\section{References}

Ahamed N (1999) A study on socio-economic aspects of coastal fishermen in Bangladesh, Bangladesh journal of Zoology 24:20-26.

Ahamed NU (1996) Reports of the fishermen's socioeconomic survey. Fisheries survey and monitoring program. Department of fisheries, Bangail. Pp4.

Chambers R, Conway GR (1992) Sustainable Rural Livelihoods: Practical Concepts for the 21st Century. IDS Discussion Paper 296 available on http://www.ids.ac.uk/publication/sustainable-rural-livelihoodspractical-concepts-for-the-21st-century access on 24th March, 2015.

Department for International Development (1999). Sustainable livelihoods guidance sheets, (DFID), London, UK.

Department of Fisheries (1993) Ministry of Fisheries and Livestock, Dhaka, Bangladesh. National Fish Week Compendium (in Bengali) Pp 144.
Department of Fisheries (2010) Ministry of Fisheries and Livestock, Dhaka, Bangladesh. National Fish Week Compendium (in Bengali) Pp 144.

Department of Fisheries (2012) Ministry of Fisheries and Livestock, Dhaka, Bangladesh. National Fish Week Compendium (in Bengali) Pp 144.

Department of Fisheries (2013) Ministry of Fisheries and Livestock, Dhaka, Bangladesh. National Fish Week Compendium (in Bengali) Pp 144.

Hannan M (1994) Fisher folk organization in Bangladesh. In: Socio-economic Issues in Coastal Fisheries Management. Proceedings of the IPFC Symposium, Bangkok, Thailand, 2326 November 1993: Indo Pacific Fishery Commission (IPFC), no. 8 , pp. 216-222.

Hossain M, Pingali PL (1998) Rice research, technological progress and impact on productivity and poverty: an overview. In: Pingali P, Hossain M (Eds.) Impact of Rice Research. Proceedings of the International Conference on the Impact of Rice Research, 3-5 June 1996, Bangkok. Thailand: Thailand Development Research Institute and Los Benos (Philippines) and IRRI, Pp 1-2, 5.

Hughes R, Adnan S, Dalal-Clayton B (1994) Floodplains or flood plans? A critical look at approaches to water management in Bangladesh. International Institute for Environment and Development (IIED), London and Research and Advisory services, Dhaka.

Kostori MFA (2012) Scio- economic condition of fishermen of the Chalan Beel under Talash thana of Sirajganj Disrtrict in Bangladesh. Bangladesh Research Publication Journal 6: 393402.

Mahbullah M (1986) Case study of polder and estuarine fishing community in Bangladesh. Socio-economic study of tropical fishing community in Bangladesh, A report for the food and agriculture organization (FAO), Rome. 1986(12-14).

Mannu MU (1999) Jeleder Sukh Dukh. The Daily Janakantha, 22 August 1999.

Minar MH, Arifur Rahman AFM, Anisuzzaman M (2012) Livelihood status of the fisherman of the Kirtonkhola River nearby to the Barisal town. Journal of Agroforestry and Environment 6: 115-118.

Rahman MM, Hassan MR (1992) A study on fish and fishermen of Kaptai Lake in Bangladesh. Report submitted in Grants Commission, Dhaka, Pp. 49.

Shamima A (2000) Socio-economic conditions of fishing community: Gallamary fish market, Khulna. A project thesis in 
Fisheries and Marine Resource Technology Discipline, Khulna University, Khulna, Bangladesh Pp 11-34.

Scoones I (1998) Sustainable rural livelihood: a framework for analysis. IDS working paper No. 72.Institute of Development studies, 1998 Brighton.
Shahjahan M, Miah MI, Haque MM (2001) Present Status of Fisheries in the Jamuna River. Pakistan Journal of Biological Sciences, 4: 1173-1176 DOI: 10.3923/pjbs.2001.1173.1176. 